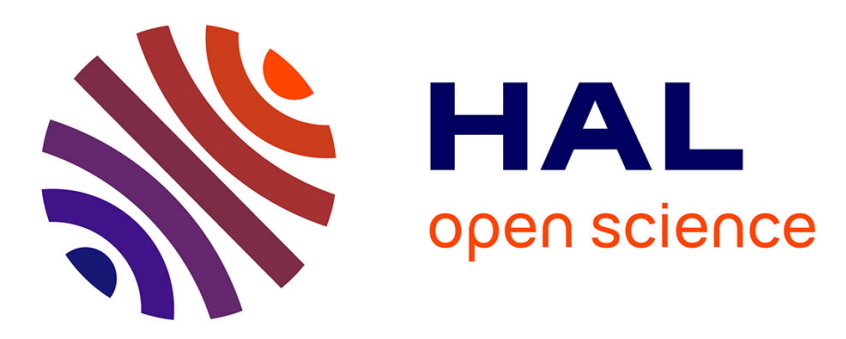

\title{
Micro-syntax, macro-syntax, foregrounding and backgrounding in discourse....
}

Francis Cornish

\section{To cite this version:}

Francis Cornish. Micro-syntax, macro-syntax, foregrounding and backgrounding in discourse....: ...When indexicals target discursively subsidiary information. Belgian Journal of Linguistics, 2012, 26, pp.6-34. hal-00965659

\section{HAL Id: hal-00965659 \\ https://hal-univ-tlse2.archives-ouvertes.fr/hal-00965659}

Submitted on 25 Mar 2014

HAL is a multi-disciplinary open access archive for the deposit and dissemination of scientific research documents, whether they are published or not. The documents may come from teaching and research institutions in France or abroad, or from public or private research centers.
L'archive ouverte pluridisciplinaire $\mathbf{H A L}$, est destinée au dépôt et à la diffusion de documents scientifiques de niveau recherche, publiés ou non, émanant des établissements d'enseignement et de recherche français ou étrangers, des laboratoires publics ou privés. 
"Micro-syntax, macro-syntax, foregrounding and backgrounding in discourse: When indexicals target discursively subsidiary information"*

Francis Cornish

CNRS, CLLE-ERSS, UMR 5263

and Département Études du Monde Anglophone,

Université de Toulouse-Le Mirail,

5, Allée Antonio Machado,

31058 Toulouse Cedex 09

Email address: cornish@univ-tlse2.fr 


\begin{abstract}
Adopting Berrendonner's (1990), (2002) and Berrendonner et al.'s (forthcoming) distinction between "micro-syntax" and "macro-syntax", as well as the orthogonal dichotomy between foregrounded and backgrounded discourse segments (cf. Khalil 2005), this paper aims to examine certain "non-canonical" interactions amongst these domains. In particular, it analyses instances where a potential referent is evoked within a highly presupposed, discursively backgrounded text segment, but where that referent is targeted via an "anadeictic" indexical expression and may be made into a discourse entity in its own right. This last-mentioned use is characteristic of discourse deixis, but not of anaphora as such. The paper also examines larger stretches of text, which relate to each other discursively in terms of "macro-syntax". The overall aim is to characterise the limits of discourse-anaphoric reference as a function of the degree of backgrounding or foregrounding of the discourse units in terms of which the referent is determined and targeted.
\end{abstract}

Keywords: foregrounding, backgrounding, discourse, anaphora, macro-syntax, microsyntax 


\section{Introduction}

This paper's goal is to determine the ways in which discourse-anaphoric and "anadeictic" reference is affected by the syntactic (textual) and discursive relations obtaining between the antecedent and indexical segments in a text. I will be making use of Berrendonner's (1990), (2002) and Berrendonner et al.'s (forthcoming) distinction between "micro-syntax" and "macro-syntax", as well as of the orthogonal relationship between degrees of foregrounding or backgrounding exhibited by certain discourse segments (cf. Khalil 2005). In this respect, I will examine in particular instances where a potential referent is evoked within a highly presupposed, discursively backgrounded textual segment in some text (for example, a restrictive relative clause, or a complement clause - both of which assume a micro-structural relation with their containing clause), but where that referent is targeted via an anadeictically-used indexical and may be made into a discourse entity in its own right. This last-mentioned use is the province of discourse deixis, but not of discourse anaphora as such. Comparisons will be made between relations involving clause-sized segments (illustrated in sections 2-4, in particular) and larger stretches of text, which relate to each other discursively in terms of "macro-syntax" (section 5). The article attempts to determine the limits of potential discourse-anaphoric reference in terms of the backgrounded or foregrounded status of the discourse units within which the referent is specified.

I begin by briefly outlining Berrendonner's distinction between the levels of "micro-" and "macro-syntax" (section 2), and then sketch the orthogonal distinction between foregrounded and backgrounded discourse units of various sizes in terms of Khalil's (2005) account (section 3). Having done this, I differentiate in section 4 amongst discourse anaphora, 'strict' anadeixis and discourse deixis. This leads to the main focus of the paper (section 5), namely the correlations that may hold between the operation of discourse deixis, 'strict' anadeixis and discourse anaphora, on the one hand, and the status of the discourse units targeted by these context-bound referring procedures as foregrounded or backgrounded units, on the other. We will see that referring via indexicals is not just a question of targeting individual referents, but involves "knitting" two entire discourse units together in terms of foregroundbackground relations.

\section{2. "Micro-" vs. "macro-syntax"}

There are in fact several extant conceptions of the micro- vs. macro-syntax distinction: the Fribourg one (represented here by Berrendonner), the Aix one (developed by the GARS/DELIC research group: see Blanche-Benveniste 2002) and the Florence school one (associated with the LABLITA research unit). See Avanzi (2007) for an illuminating comparison of these different approaches. In Berrendonner's (1990), (2002) and Berrendonner et al.'s (forthcoming) conception, micro- and macro-syntax are types of ways in which more basic units within each domain may be integrated into a larger, more encompassing structure. In the case of micro-syntax, these units are lexical heads, phrases and clauses, ${ }^{1}$ and in that of macro-syntax, they are minimal

\footnotetext{
${ }^{1} \mathrm{I}$ am using this term in its general sense in linguistics. This is not to be confused with Berrendonner's usage of this term, which characterizes the constituent that is the maximal unit within "micro-syntax".
} 
discourse units. While micro-syntax is the domain of government (French "rection") by phrasal heads of their complement(s) and by groups and phrases of their modifiers or adjuncts, macro-syntax (also termed "pragma-syntax": i.e. the lexico-grammatical as well as discourse relations spanning adjacent sentences or clauses within a text) is the domain of coherence or rhetorical relations between discourse units, each of which may serve to augment the discourse model ("mémoire discursive") being constructed as the co-text unfolds.

One central initial test - though currently under discussion: cf. Berrendonner et al. (forthcoming) - of whether a given unit is related to another in terms of micro- or macro-syntax is the possibility of felicitously using an appropriate definite lexicallyheaded NP to replace a $3^{\text {rd }}$ person pronoun in the second unit which is in some anaphoric relation with an antecedent expression in the first. Obviously, this test is only applicable where there exists an anaphoric $3^{\text {rd }}$ person pronoun in a non-initial unit retrieving a referent evoked in the initial one. If such a substitution is possible, preserving the anaphoric relation initially established, then we may be dealing (at the level of utterance processing) with an incrementation of the discourse model under construction, and therefore with an instance of macro-syntax -although in Berrendonner's later work (Berrendonner et al. forthcoming), the possibility remains that other factors may still indicate that the two segments at issue are connected in terms of a micro-syntactic relation of some kind. While if this substitution is impossible, then other things being equal, the relation may be one of micro-syntax. A purely grammatically-determined (micro-syntactic) relation has none of the implications associated with macro-syntax: it simply indicates "what goes with what", and "in what way", at the level of grammatically-determined textualisation. It will be subject to the usual tests of dependency, all grammatical relations holding up to the level of the sentence. ${ }^{2}$ Beyond a given sentence, we enter the realm of inter-sentential relations, which is the province of discourse (and hence of "macro-syntax"). However, as we shall be seeing in due course, macro-syntactic relations may in fact hold within as well as outside the sentence boundary (cf. also Blanche-Benveniste 2002, 98, 112, 117).

There is an evident (partial) parallel between Berrendonner's notion "microsyntax" and that of text in my conception (see Table 1 below, as well as Cornish 2010, 208-10), as also between his notion "macro-syntax" and my view of discourse (cf. Table 1). Micro-syntactic relations holding between syntactic units would form part of what I am calling text, which embraces the entire perceptible trace of an act of utterance. As such, this includes paralinguistic features of the utterance act, as well as non-verbal semiotically relevant signals such as gaze direction, pointing and other gestures, etc. But under the Fribourg conception, such non-verbal signals would fall within the set of means of expression ("actualisation") of discourse, and would not form part of its notion of "micro-syntax".

Discourse in my approach refers to the structured, situated, revisable interpretation of utterances in conjunction with an appropriate context. Text provides the perceptible cues which, in conjunction with a relevant context, will enable the user to

\footnotetext{
2 Berrendonner in fact does not recognize the traditional grammatical unit "sentence" as a relevant constituent within the "micro-"/"macro-syntax" distinction. The use in context of a complex sentence (which is what I have in mind in using the term here) would correspond to a "period" in the Fribourg conception. Blanche-Benveniste $(2002,102)$ in fact claims that the sentence is a "macro-syntactic", not "micro-syntactic" unit, under her conception of the distinction.
} 
construct discourse (see Cornish 2010 for further details).

Table 1: The respective roles of text, context and discourse (Cornish 2010:Table 1, p.209, revised)

\begin{tabular}{|l|l|l|}
\hline \multicolumn{1}{|c|}{ Text } & \multicolumn{1}{c|}{ Context } & \multicolumn{1}{c|}{ Discourse } \\
\hline $\begin{array}{l}\text { The connected sequence of } \\
\text { verbal signs and nonverbal } \\
\text { signals in terms of which } \\
\text { discourse is co-constructed } \\
\text { by the discourse partners in } \\
\text { the act of communication. }\end{array}$ & $\begin{array}{l}\text { The context (the domain of reference of a given } \\
\text { text, the co-text, the discourse already } \\
\text { constructed upstream, the genre of speech event } \\
\text { in progress, the socio-cultural environment } \\
\text { assumed by the text, the interactive relationships } \\
\text { holding between the interlocutors at every point } \\
\text { in the discourse, and the specific utterance } \\
\text { situation at hand) is subject to a continuous } \\
\text { process of construction and revision as the } \\
\text { discourse unfolds. It is by invoking an } \\
\text { appropriate context that the addressee or reader } \\
\text { may create discourse on the basis of the } \\
\text { connected sequence of textual cues that is text. }\end{array}$ & $\begin{array}{l}\text { The product of the hierarchical } \\
\text { situated sequence of utterance, } \\
\text { indexical, propositional and } \\
\text { illocutionary acts carried out in } \\
\text { pursuit of some communicative } \\
\text { goal, and integrated in a given } \\
\text { context. }\end{array}$ \\
\hline
\end{tabular}

Examples (1) and (2) below, taken from English "news-in-brief" newspaper articles, illustrate this distinction:

\section{a. "US orders staff out of Uzbekistan}

The US and Israel have withdrawn [non-essential diplomatic staff and their families $]^{3}$ from Uzbekistan, after warnings that they ${ }_{\mathrm{i}}$ could be targeted by Islamic militants. The move came after weeks of unrest in the wake of the massacre of hundreds of civilians in the town of Andijan last month." (The Guardian Weekly, June 10-16, 2005, p. 2)

b. The US and Israel have withdrawn [non-essential diplomatic staff and their families from Uzbekistan, after warnings that the group $_{i}$ could be targeted by Islamic militants...

Replacing the $3^{\text {rd }}$ person subject pronoun they in the modifying prepositional phrase introduced by after in (1a) by the definite NP the group, an NP capable of targeting the same referent, is (relatively) felicitous in (1b), in that the anaphoric link realised via the pronoun they in (1a) is maintained. And indeed, this PP is clearly only loosely connected, in grammatical terms, with the initial clause. Its function is that of a sentence adverbial, providing the reason for the state of affairs evoked via the initial (main) clause. We are therefore (by hypothesis) dealing with a macro-syntactic relation here. However, as Laure Anne Johnsen (p.c.) indicates, with the exception of the possibility of felicitous substitution of the pronoun by the definite NP here, the cues in this example point towards a micro-syntactic analysis - at least under the Fribourg conception. This is so, according to her, since the modifying PP is not autonomous morpho-syntactically, so could not constitute a "clause" in Berrendonner's terms. But the fact remains that this modifying PP is only loosely connected with the main clause (the presence of the comma indicates this formally); and it is this which has enabled the NP's substitution to be felicitous. The "macro-syntactic" status of sentential modifiers (so-called "compléments de phrase") also corresponds to Blanche-Benveniste's (2002, $100)$ position. So this factor would argue in favour of a more gradual, scalar conception

\footnotetext{
3 In the following examples, square brackets have been inserted around textual antecedents and a subscripted letter placed before the closing square bracket, with the emboldened anaphoric expression marked with an identical subscript. This is in order to indicate the referential identity intended.
} 
of the "micro-" vs. "macro-syntax" opposition, which I will indeed be arguing for below. Let us look now at example (2):

(2) a. "[Investors in the beleaguered oil firm Yukos $]$ have been told by a Russian court that they $_{\mathrm{j}}$ can have no role in the organisation's bankruptcy. Analysts believe the state is attempting to renationalise the remains of the company." The Guardian Weekly, 713/04/06, p. 28

b. \#[Investors in the beleaguered oil firm Yukos ${ }_{j}$ have been told by a Russian court that the shareholders $\mathrm{j}_{\mathrm{j}}$ can have no role in the organisation's bankruptcy...

Contrary to what we have seen in (1), in (2b) it would not be possible to substitute an appropriate definite NP (the shareholders) for the subject pronoun they in the governed subordinate clause introduced by that, preserving the anaphoric relation with the matrix clause subject. It would seem, then, that the relationship between the initial predication and this subordinate clause is a micro-syntactic and not a macro-syntactic one. Another indication of this relationship is the impossibility of deleting the subordinate clause in (2a): *Investors in the beleaguered oil firm Yukos have been told by a Russian court. Compare this result with the naturalness of a deletion of the counterpart prepositional phrase in (1a): The US and Israel have withdrawn non-essential diplomatic staff and their families from Uzbekistan. After all, the subordinate clause in (2a), unlike the counterpart PP in (1a), realises a nuclear grammatical function - that of second object of the verb told ('to tell someone something'), and is therefore a lexically governed unit.

It would seem then that the distinction between micro- vs. macro-syntactic relations involving textual or discourse units is a matter of degree rather than being an absolute, categorical one (which it clearly is under the Fribourg conception of the opposition, where a "macro-syntactic" relation between units can only hold between "clauses" representing actualised utterance acts). That is, it is in principle possible for a given textual unit to contract a (relatively) loose micro-syntactic relation with a controlling syntactic unit, but at the same time, as a potential unit of discourse, to enter into a discourse-pragmatic relation with some other such unit on the discourse plane. This "intermediate" position would be reflected by the possibility of the pronoun substitution test resulting in an indeterminate or unclear outcome - a situation which will be familiar to those working on indexical relations in discourse. As already indicated, this possibility is ruled out under the Fribourg conception of the "micro-" vs. "macro-syntax" distinction - though not by the Aix one (see Blanche-Benveniste 2002).

The distinction may have something to do with logophoric relations: ${ }^{4}$ where the relation between the proposition expressed by the subordinate clause and the matrix one is such that it represents the viewpoint of a matrix clause NP's human referent (the "sujet de conscience"), then a lexical expression coreferential with it but which the intended referent would not have used in referring to himself, results in a bizarre reading. In my view, this is why a $3^{\text {rd }}$ person pronoun would be expected, as maintaining logophorically the "sujet de conscience" from the matrix clause. Three examples from Chomsky (1986, 79-80) establish the point clearly (though Chomsky was concerned with a different issue in presenting them):

\footnotetext{
4 'Logophoricity' "refers to the phenomenon whereby the 'perspective' of an internal protagonist of a sentence or discourse, as opposed to that of the current, external speaker, is being reported by some morphological and/or syntactic means.” (Huang 2000, 172-3).
} 
(3) a. Reagan ${ }_{i}$ was elected, although the former actor ${ }_{i}$ is regarded by many with a good deal of skepticism. (Chomsky's 1986 ex. (48(i)), p. 79)

b. Reagan ${ }_{i}$ 's main problem is that the former actor $_{i}$ is regarded by many with a good deal of skepticism. (Chomsky's 1986 ex. (48(ii)), p. 80)

c. * Reagan ${ }_{i}$ is aware that the former actor $_{i}$ is regarded by many with a good deal of skepticism. (Chomsky's 1986 ex. (49), p. 80)

In (3a) and (3b), the referent 'Ronald Reagan' is being viewed from the perspective of 'many (people)', and so the lexical expression the former actor is an appropriate means of targeting this individual in the subordinate clause, maintaining that perspective; however, in (3c), the same lexical expression is infelicitous, ${ }^{5}$ as in the case of $(2 b)$ above with the alternative referent-maintaining NP the shareholders, since the content of the (here lexically governed) subordinate clause is being presented from the viewpoint of Reagan himself, as sujet de conscience of the entire discourse fragment. However, using a $3^{\text {rd }}$ person pronoun (here $h e$ ) in place of the definite indexical NP in (3c) would be perfectly coherent. So (2b) and (3c) would both be pragmatically infelicitous for the same kind of reason: in terms of discourse, they involve "crossed perspectival wires", as it were - even though in direct discourse, the reporting expression the shareholders in (2b) would correspond to a $2^{\text {nd }}$ person pronoun (you), whereas in $(3 \mathrm{c})$, it would correlate with a first-person one $(I)$.

\section{Backgrounded vs. foregrounded discourse units}

Backgrounded vs. foregrounded units may be either micro-syntactic or macro-syntactic, in Berrendonner's (1990), (2002) and Berrendonner et al.'s (forthcoming) terms. Syntactically, a given clause or phrase may be dependent with respect to a governing unit (lexeme, group, phrase or clause), and hence represent a backgrounded unit in purely formal, syntactic (textual) terms; but at the same time, in terms of discourse it may constitute foregrounded information in relation to the situation evoked via what may be analysed as its governing unit in syntactic terms. An attested oral example is given in (4):

(4) 'He's pushing forty, he's developing a middle-aged spread, but Mohammed Ali has just made a bid for the heavyweight boxing championship of the world..." (Oral utterance, $B B C$ Radio 4: Today programme)

Here, the two initial clauses of this extract may be analysed as (paratactically connected) main clauses, syntactically, in relation to the following clause introduced by but: this clause may not occur independently of them, as a potentially main clause, initiating a discourse - though it may when uttered in a presuppositional context of the relevant kind. Yet in terms of discourse organisation, it is clear that the central information is conveyed by this clause, for which the two paratactic initial (potentially main) clauses act as anchoring context. The connective but is thus interpreted in this context as marking a concessive and not a purely oppositional relation between the two units: an appropriate paraphrase making explicit the discourse corresponding to this

\footnotetext{
5 I would prefix the example with the crosshatch rather than the asterisk Chomsky uses to characterize its status. After all, there is nothing wrong with the well-formedness of (3c) qua sentence; rather, it is the discourse to which it will give rise by default which is problematic.
} 
textual fragment might be as follows: "Although he may be pushing forty, and although he may be developing a middle-aged spread, Mohammed Ali has nevertheless just made a bid for the heavyweight boxing championship of the world".

The intonation pattern corresponding to the two initial clauses as uttered involved a fall-rise (continuative) contour in each case, whereas the one with which the final clause was pronounced manifested a falling (conclusive) contour. ${ }^{6}$ It is a "denial of expectation" use of but: there is necessarily a pause (as here) between the preceding (paratactic) clause(s) and the clause prefixed by but; and there is no requirement that the two units connected thereby be of equal rank, syntactically (as would be the case for coordinator but - cf. Kies 1994).

Notice also how the presence of $3^{\text {rd }}$ person pronoun (hence referentially highly dependent) subjects in the two initial main clauses, linked paratactically, reflects the discursively subordinate, background status of these units, in relation to the following clause introduced by the connective (cf. also Mittwoch 1983, 134). Likewise, the presence of a full proper name, Mohammed Ali (a referentially-autonomous expression) in subject position, reflects the discursively foreground status of this unit. In terms of the micro- vs. macro-syntax distinction, I would argue that we have to do with three macro-syntactic units here (this would also be the Fribourg School position, as Laure Anne Johnsen (p.c.) points out) since at least the subject pronoun in the first of the two initial clauses may coherently be replaced by a definite lexical NP (e.g. the man), preserving the coreferential-anaphoric relation with the "antecedent" NP Mohammed Ali in the third. ${ }^{7}$ Moreover, none of the clauses at issue is connected with the other(s) as a grammatically governed unit.

In example (1a) above, the adverbial PP introduced by after is both (loosely) dependent — hence backgrounded — syntactically and subsidiary (i.e. also backgrounded) informationally, in that it serves to motivate the central situation evoked via the initial main clause. Conversely, in (2a), although the subordinate clause introduced by that is highly dependent (being a lexically governed unit, hence syntactically backgrounded), in terms of the organisation of the message corresponding to this text fragment as a whole, it conveys the key information. So it is a foreground, not a background unit in discourse terms. This distinction can be brought out using Erteschik-Shir's $(2007,39,164)$ so-called "lie test": if it is felicitous to contradict a given phrase or clause within an utterance, then that phrase or clause is asserted (conveys focal information in context) and is not presupposed. However, if the contradiction is infelicitous, then it will correspond to backgrounded and not to foregrounded information. The test should be construed in relative, not absolute terms: the relative degree of ease with which the contradiction may be realised reflects the degree of "foregroundedness" of the information unit at issue. See the very similar test used by Boye and Harder $(2009,21)$ in terms of what the authors call "addressability" as applied to their Danish examples (16) and (17). Let us apply the "lie" test to the subordinate clause in $(2 a)$ :

(2) a.' A to B: Investors in the beleaguered oil firm Yukos have been told by a Russian court that they can have no role in the organisation's bankruptcy.

\footnotetext{
${ }^{6}$ Cf. Mittwoch's $(1983,134)$ observation concerning the backwards-anaphora compound sentences whose conjuncts are connected by but which she presents in her article.

7 See Mittwoch (1983) for further examples and discussion of the kinds of discourse motivations behind the use of backwards anaphora where the anaphor(s) occur(s) in a non-dependent clause preceding its/their textual antecedent.
} 


\section{B: But that's not true: they CAN ('have such a role')!}

The result is positive, showing that the subordinate clause represents asserted, ${ }^{8}$ thus focused (i.e. foregrounded) and not presupposed, backgrounded information. The same test would yield a positive result when applied to (4), as shown by (4a):

(4) a. A to B: He's pushing forty, he's developing a middle-aged spread, but Mohammed Ali has just made a bid for the heavyweight boxing championship of the world.

B: That's not true! He HASn't ('just made a bid for the heavyweight boxing championship of the world')!

B's contradiction here relates to the claim made in the foregrounded part of (4) (what is conveyed by the but clause).

Compare this with the relatively strained objection relating only to what is conveyed by the paratactically connected main clauses. See (4a'):

(4) a.' A to B: He's pushing forty, he's developing a middle-aged spread, but Mohammed Ali has just made a bid for the heavyweight boxing championship of the world.

B: ?\# That's not true! He ISn't ('pushing forty and developing a middle-aged spread')!

Philippe de Brabanter (p.c.) points out that the reason why B's retort is infelicitous here may have to do with distance: by the time B speaks, it is possible that 'pushing forty and developing a middle-aged spread' is no longer topical and cannot, therefore, be easily targeted by a denial. This is no doubt true, but this would only heighten its relatively backgrounded status at this point in the discourse. The concessive value in context of the conjunction but and the continuative-conclusive intonation structure clearly show, independently, that the first two clauses convey background, and the last, foreground information here.

The contrasting results yielded by this test show, then, that the syntactically main clauses in (4) express background rather than foreground information, the contradiction via negation proving more difficult than the parallel contradiction of the syntactically coordinate (i.e. non-independent) clause introduced by the connective, as in (4a) above.

As suggested in section 2 in relation to the micro- vs. macro-syntax relationship, the foreground-background distinction in discourse also admits of degrees, and is not a categorical one (cf. also Givón 1987; Khalil 2005). Khalil suggests that it may operate in different ways at different levels, in fact. See Table 2 below:

\footnotetext{
${ }^{8}$ Philippe de Brabanter (p.c.) points out that the complement clause cannot be said to be "asserted" by the speaker of (2a), since $s$ /he is not necessarily committed to its truth. However, this is in fact an instance of indirect reported speech; as such, it is clear that from the point of view of the 'Russian court' (the primary locutionary source for the reported speech segment), the complement clause proposition is indeed asserted in the sense that its primary locutionary source is committing itself to the truth of the proposition asserted. So in fact the Guardian journalist here is simply reporting an earlier assertion corresponding to the content of the complement clause. De Brabanter also notes that in the case of (4a), the speaker (A) is clearly committing himself to the proposition expressed by the butclause, and hence this may be taken to be asserted. But notice also that in (4a), unlike (2a), there is only a single locutionary source involved, namely the actual speaker (in (4), the radio journalist).
} 
Table 2. Levels of grounding according to Khalil (2005) (Table 1 "Notions used in this study", Khalil, 2005,3)

\begin{tabular}{|l|l|l|}
\hline Notion & Domain & Description \\
\hline Figure-Ground & $\begin{array}{l}\text { visual perception } \\
\text { cognition }\end{array}$ & $\begin{array}{l}\text { Objects are perceptually organized } \\
\text { relative to each other. }\end{array}$ \\
\hline $\begin{array}{l}\text { Grounding (foreground-background) } \\
\text { structure }\end{array}$ & text semantics & $\begin{array}{l}\text { The organization of semantic } \\
\text { representations or the propositional } \\
\text { content in terms of a grounding scale, } \\
\text { distinguishing various grounding } \\
\text { values. }\end{array}$ \\
\hline Information structure & cognition & $\begin{array}{l}\text { One way in which knowledge is } \\
\text { (hierarchically) organized in models. } \\
\text { It is textually constructed in semantic } \\
\text { representations, that is, meaning and } \\
\text { its organization in text. }\end{array}$ \\
\hline Prominence & text strategy & $\begin{array}{l}\text { Surface structure organization. The } \\
\text { relative conspicuousness of sentences } \\
\text { and their constituents as result of } \\
\text { their linear organization. }\end{array}$ \\
\hline Foregrounding \& backgrounding & text pragmatics & $\begin{array}{l}\text { Surface structure operations that } \\
\text { make sentences and their constituents } \\
\text { more or less prominent and influence } \\
\text { the interpretation of text meaning in } \\
\text { terms of grounding values that have } \\
\text { already been assigned to propositions. }\end{array}$ \\
\hline
\end{tabular}

As can be seen, Khalil draws a five-way distinction amongst "figure-ground", which has to do with perception and the resulting cognition; "grounding (foregroundbackground) structure", which relates to text semantics ("the organization of semantic representations or the propositional content in terms of a grounding scale, distinguishing various grounding values"); information structure, which concerns how meaning is organised in texts; "prominence", determined by a given text strategy, defined as "...the relative conspicuousness of sentences and their constituents as a result of their linear organization" (p. 3); and finally, "foregrounding and backgrounding", which are bound up with text pragmatics." These are said to be "surface structure operations that make sentences and their constituents more or less prominent and influence the interpretation of text meaning in terms of grounding values that have already been assigned to propositions." The key point that seems to be at issue here is the fact that users are not "condemned" to organise their utterances in terms of the perceived "figure-ground" structure of the situation which they wish to verbalize; but that what they choose to foreground and/or to background in their message is a function of their communicative intentions.

The possible default grounding values are foreground, midground and background. As argued above, Khalil $(2005,4)$ observes that syntactic organisation does not of itself assign grounding values (e.g. syntactically non-independent clauses, as in (2b) and (4) above, do not always convey subsidiary, background information; and

\footnotetext{
9 The distinctions between "prominence", "information structure" and "foregrounding" and "backgrounding" are not fully clear, however - unless it is intended that part or all of an utterance becomes prominent and foregrounded (or non-prominent and backgrounded) as a result of the imposition of a given information structure upon it. In any case, we may wonder why the notion "prominence" is needed alongside "information structure", and "foregrounding" and "backgrounding". After all, if a speaker chooses to "foreground" a discourse unit, then it will of necessity be "prominent" in terms of surface structure (i.e. lexico-grammatical realisation); while if s/he elects to "background" it, then it will evidently not be prominent, surface-structurally.
} 
syntactically main clauses, as in (4), do not always express foreground information). Grounding values are genre-specific: for example, in written news articles, the value "foreground" tends to be assigned to macro-propositions. These denote the key event or situation which the article as a whole develops. The value "background" will tend to be assigned to propositions expressing circumstantial information (the spatio-temporal setting of the main event or situation). This is what "grounds" or anchors the central information derived from the text and a suitable context. See de Vega et al. (2007) for experimental evidence in favour of the background status of preposed temporal clauses in German and Spanish introduced by the equivalents of while. See also Auer $(2009,86)$ who quotes from Duranti and Goodwin $(1992,10 \mathrm{ff})$ in stating that "'focal events' as figures are perceived as "well outlined, sharply defined and well articulated", while contexts as grounds "appear far more amorphous, problematic, and less stable"". Finally, the value "midground" may be attributed to propositions that elaborate or explain the main event.

In terms of prominence, which is a surface-structural property of texts, the point is made that what is made prominent textually may not be foreground meaning, but may enjoy a relatively lower grounding value: "...prominence and importance are independent of each other" (Khalil 2005, 6). Khalil (p. 7) goes on to write of "figure and ground slots" in text structure, which may be filled by clauses expressing background, midground or foreground propositions. Foregrounding and backgrounding are pragmatic operations with surface-structural implications, whereas foreground and background are characteristics of the semantic structure of the clauses concerned (Khalil 2005, 11).

In the examples discussed so far, the background or foreground units at issue have mostly been clauses. However, when longer texts are taken into account, it is clear that each status may characterize much larger segments of text. In narrative texts, for example (see Jadir 2005, 238-257), the foreground sequences of actions being recounted may be interrupted by background descriptions (of a scene or a character), or by a flashback or a series of flashbacks to an earlier situation in which the character(s) concerned may have been involved (see examples (10) and (11) below for illustration). These interruptions often serve to explain the motivations of the characters involved at the point of interruption. Whereas the time-line of the central narration will be realised by simple past (preterit) or (historic) present tenses carried by the finite verbs involved, ${ }^{10}$ the interrupting descriptive or explanatory sequences will tend to be realised as far as tense is concerned by the past perfect (French plus-que-parfait), the simple present tense or the present or past progressive (imparfait in French). The corresponding French devices are invoked here for purposes of comparison. The last-mentioned types of tense/aspect (apart from the past perfect/plus-que-parfait) have as a common feature the expression of an imperfective aspect (see also Khalil 2005, 3). However, where the shift to an earlier state of affairs is explicitly marked (e.g. via a temporal adverbial), the tense of the finite verbs in a background unit may still be the simple past, a tense type also typically used for the main time-line development in the foreground narrative units. $^{11}$

\footnotetext{
10 Prototypically by the passé simple, in French. However, I do not wish to imply that this tense, or indeed the other French tenses mentioned in the text above and below, function in exactly parallel fashion with respect to their English counterparts.

11 See also Hopper (1979), Reinhart (1984), Dowty (1986), Gennari (2004) and Madden and Zwaan (2003) on this issue.
} 


\section{Discourse anaphora, 'strict' anadeixis and discourse deixis}

In my view (see Cornish 1999, 2010), deixis and discourse anaphora are complementary discourse-referring procedures which the user exploits in constructing, modifying and accessing the contents of mental models of an unfolding discourse represented in the minds of speaker and addressee (or writer and reader in the written form of language). Basically, deixis and anaphora are procedures for coordinating the speech participants' attention throughout the flow of text as produced within a given context to which they are both party (see in particular Clark and Bangerter 2004 on this issue, in terms of the act of referring more generally).

Both discourse anaphora and deixis, then, operate at the level of memory organization, enabling the speaker to manage it by guiding the addressee's processing of the incoming segments of a text (cf. also Ehlich 1982, 325, 330). Deixis under this view involves the use of the speech situation (the (deictic) ground, in Hanks' 1992 terminology) to profile a figure (a new referent or a new conception of an existing referent within the discourse registry). A canonical example is given in (5):

Hey, look at that! [The speaker gestures towards a strange-looking bird perched on a branch of a nearby tree]

Here, the existence of the intended referent ('the strange-looking bird on the tree close to the interlocutors'), which is available within the utterance context, is being drawn to the addressee's attention as a function of the very act of utterance involved. It is not presupposed already to exist and to be salient within the latter's attention focus, as is the case with canonical anaphoric references. Rather, its existence is asserted (or, more accurately, demonstrated). The distal demonstrative that (and not proximal this) is used here, since the speaker's intention is evidently to secure a joint orientation of the interlocutors' attention focus on the intended referent. The deictic procedure adopted results in the intended referent "standing out" from within its context, thereby acquiring a high level of psychological salience for both speaker and addressee; so it is introduced into the discourse as a new unit of information.

By contrast, anaphora consists in the retrieval via a referentially-dependent indexical expression token from within a given ground of an already existing 'figure' (or one which may be relatively easily accommodated or otherwise inferred from context), together with its 'ground', the anaphoric predication acting to extend that ground (see Kleiber 1994, Ch. 3) - i.e. to carry it over for the interpretation of the current utterance. The occurrence of an anaphor together with the clause in which it occurs as a whole constitutes a signal to continue the focus of attention established - or assumed to be established - at the point of use. For a canonical example of anaphora, see the occurrence of $i t$ in the possible continuation of the utterance in (5):

$$
\text { a. ...I wonder how it got there. }
$$

The occurrence of it in (5a) presupposes that its intended referent is already known to the addressee and is indeed uppermost in his/her mind at the time of utterance. That is, it is already highly salient psychologically, and so requires only minimal coding. Examples (1), (2), (3a,b) and (4) above provide further illustrations. The "figure/ground" relation is thus an integral part of the operation of these two indexical 
referring procedures. See also Sidnell $(2009,118)$ for this conception as regards the operation of deixis in discourse. See Cornish $(2010,218-223)$ for further discussion of the deixis/discourse anaphora distinction.

Pure deixis is canonically realised by the use of $1^{\text {st }}$ and $2^{\text {nd }}$ person pronouns. These are "token-reflexive" in that their very use in context automatically yields their referent (current speaker and current addressee, respectively - or referents that include current speaker and addressee). As such, a token of one of these form types cannot be used anaphorically. At the other extreme are $3^{\text {rd }}$ person reflexive pronouns, whose referent is determined quasi-automatically in terms of semantic-syntactic factors within the host clause as a bound anaphor. A token of this form type (when unstressed in English) cannot be used deictically.

Yet the relationship between deixis and anaphora is asymmetrical: these are by no means "absolute" or autonomous indexical referring procedures. As Lyons (1975) convincingly argued (cf. also Bühler 1990/1934, Gerner 2009 and others), anaphora is derivative upon deixis, on which it depends. Deixis is the more fundamental referring procedure. The majority of indexical expression types capable of realising anaphora may also have a deictic function (or are morphologically derived from those that are specialised in this use). The real relationship between these two indexical procedures may be characterised in terms of a cline, with a medium term: this intermediate, hybrid level has been termed "anadeixis" by Ehlich (1982). See Figure 1 in Cornish (2010 221).

Thus in between the two polar types of indexicals $\left(1 \mathrm{st}\right.$ and $2^{\text {nd }}$ person pronouns, and 3rd person reflexive pronouns) we find a range of expression types - mainly demonstrative-based — which may be called "anadeictic": see Ehlich (1982, 333-4). The use of one of these expression types involves partly anaphoric, and partly deictic reference. It exploits the basic (i.e. "situational") deictic procedure as applied to the discourse already constructed (or shortly to be constructed) - hence also the "anaphoric" dimension of this usage. See example (6) for an attested (written) illustration of what I am calling 'strict' anadeixis:

(6) “...'We use Viking as a shorthand term and there's the traditional raping and pillaging image of the Vikings. That was replaced in the 1970s by what I think of as the fluffy bunny school of Viking studies...". (Extract from article by Mark Brown "'Stunning' Viking find of silver coins and jewellery bought for the nation", The Guardian 28.08.09, p. 12). (Example (9) in Cornish 2011)

In (6), the referent of the ('strict') anadeictic demonstrative pronoun that is introduced in the initial sentence of the extract via a predicative phrase ('there's [the traditional raping and pillaging image of the Vikings]') — what's more, in focus position within an existential construction. The demonstrative could not be replaced completely felicitously via a simple pronoun (it here: ? It was replaced in the 1970s by...). This is because it is not yet installed as a topic in the reader's mental model of the discourse being constructed (the host sentence constitutes a 'thetic, "all-new information" judgement'), and needs a stronger indexical reference in order to achieve this successfully: the distal demonstrative pronoun fits the bill admirably here. Note also the distancing effect of the use of that, in referring to the earlier image in question which has been replaced by the more recent one.

A second sub-type of anadeixis is so-called "recognitional" anadexis, whereby an expanded distal demonstrative expression or an expanded definite NP is used to locate 
an item of shared knowledge from within the addressee's long-term memory, and raise it to consciousness (as in Do you remember that time we got rained out camping in Spain?). See Cornish $(2011,758-9)$ for further discussion.

The third sub-type of anadeixis, discourse deixis, involves contextual pointing to a part of the recently constructed discourse representation, and building it into a discourse entity which may subsequently be retrieved via an anaphor. ${ }^{12}$ In this type of contextual reference, the reader or addressee must create a referent from within the immediate discourse context. ${ }^{13}$ Clearly, it is demonstrative expressions which are specialised in this function. (See as illustration examples (7)-(9) below, and for further discussion, Cornish 2011, 759-60). The demonstrative, guided by the predicative component of the indexical clause as a whole, "points" to the relevant part of the context representation; and the process of understanding it actually creates a referent out of that representation. Unlike Piwek et al. $(2008,697)$, I do not believe it is just a form of "anaphora", simply because its function is to relate to prior (or subsequent) discourse. For unlike anaphora (or indeed, "strict' anadeixis"), with discourse deixis there is no independently existing discourse entity upstream "waiting" for its reference to be picked up by a discourse-deictically used expression. Diessel $(1999,101)$ claims that the referent of such demonstratives "has no existence outside of the universe of discourse in the physical world." Another distinctive property of this use, again according to Diessel, is the fact that the referent thereby established tends not to persist in the subsequent discourse.

Figure 1 below presents the various indexical referring procedures mentioned so far, in terms of a scale of indexical referring possibilities ranging from canonical deixis to canonical discourse anaphora at each pole. The "anadeictic" span on this Scale ranges from "discourse deixis", towards the pure deictic pole, through "recognitional" anadeixis, to "strict' anadeixis", near the pure anaphora one.

\section{canonical deixis $>$ discourse deixis $>$ recognitional anadeixis $>$ 'strict' anadeixis $>$ canonical discourse anaphora}

Figure 1: Scale of indexical referring procedures (Fig. 2 in Cornish, 2011: 760)

Examples (7) through (9) below involve a demonstrative NP or pronoun within a pragmatically foregrounded unit targeting the result of processing a text segment that forms part of a pragmatically backgrounded unit: namely, a restrictive relative clause in (7), conveying presupposed information, a presupposition associated with an indefinite NP in (8), and an inference ("writing a musical inevitably takes a considerable amount of time") in (9).

To illustrate the distinction between discourse anaphora and discourse deixis, the occurrence of the demonstrative NP those boring Sundays in example (7) (line 3) is particularly interesting:

\footnotetext{
12 See Diessel (1999, 100-105), (2006, 475-6) and what Lyons $(1977,668)$ calls "impure textual deixis".

13 Diessel $(1999,93)$ characterizes discourse deixis achieved via demonstratives as "refer[ence] to propositions; they link the clause in which they are embedded to the proposition to which they refer." However, as those boring Sundays in (7) and that amount of time in (9) below, in particular, attest, discourse deixis via demonstratives is by no means limited to reference to propositions.
} 
their lawn in the past 25 years. But one listener to last year's The First Cuckoo and the Last Swallow on Radio 4 counted those boring Sundays and has now proved to be one of the many extremely important contributors to a nationwide nature diary..." ("Return of the First Cuckoo" (3.45pm R4), Radio Times 5-11.08.06, p. 132)

This is an example of discourse deixis in that it requires the reader to construct out of the discourse context an entity such that the people who "keep obsessive records about how often they have mowed the lawn in the past 25 years" do so once a week "on Sundays" (i.e. at the end of any given week), and that the obsessive recording of the fact is a boring, routine activity. These two concepts ("boring" and "Sundays") are implicitly predicated within the distal demonstrative NP, so this is consistent with the contribution of new, but context-related information that is associated with the (ana)deictic use of demonstratives. Discourse deixis is the sub-type of anadeixis that is closest to pure (canonical) deixis (see Fig. 1 above). Notice how the referent of those boring Sundays is constructed from within an informationally subsidiary textual segment (the restrictive relative clause who...years in lines 1-2 of the example) which is clearly in a micro-syntactic relation with regard to its containing NP.

The content of this relative clause corresponds to presupposed and not asserted information, and as such is backgrounded in terms of its discourse status. It is presupposed since the whole point of the NP is to evoke a stereotypical type of person - the stereotype being conveyed via the relative clause. As such, the writer assumes that there are such people, and that the reader will readily recognize their existence. Not only would Erteschik-Shir's (2007) "lie-test" yield a negative result when it is attempted to contradict the content of the restrictive relative clause (see section 3 above), but the "reporting" test using the reporting verb tell (cf. Griffiths 2006, 147) would also be negative here. ${ }^{14}$ As in (4), the second sentence prefaced by the conjunction but (here assuming a quasi-adverbial function: see Kies 1994) will convey the most prominent (foregrounded) information, the initial sentence as a whole then being construed as background, grounding the main information to come. The two sentences obviously contract a macro-syntactic relation with one another, in Berrendonner et al.'s (forthcoming) terms.

Let us look now at a further attested, but spoken, example involving a contrastively-accented demonstrative (see Chapman 1998 on the interpretative effects of accenting in English).

(8) a. [Interview with Jonathan Porritt, then leader of the environmental pressure group Friends of the Earth, by Nicholas Witchell, BBC Radio 5, 16 October, 1994]

NW: do you think that he ['Prince Charles'] will become a GREEN monarch?

JP: well, yes, but I don't think that everyone necessarily subscribes to THAT.

$\mathrm{L}+\mathrm{H}^{*} \mathrm{~L}-\mathrm{L} \%{ }^{15}$

\footnotetext{
${ }^{14}$ Compare (i) and (i)' below:
}

(i) A: "There's a word for people who keep obsessive records about how often they've mowed their lawn in the past 25 years...".

B, reporting this to C: ? "A told me that people keep obsessive records about how often they've mowed their lawns in the past 25 years...".

(i)' [Same context as (i)] B to C: "A told me that there's a word for people who keep obsessive records about how often they've mowed their lawn in the past 25 years...".

15 I use Pierrehumbert \& Hirschberg's (1990) notation system for intonation here, as follows: 'L' = 'low pitch syllable', 'H' = 'high pitch syllable'; '*'= 'accented syllable'; '\%’ = 'intonation phrase boundary syllable' '_' = 
NW: -- what, that he will ever one day beCOME king?
JP: yes. (Example (2.8a) in Cornish 1999:30).
b. ...JP: \#...well, yes, but I don't think that everyone necessarily subSCRIBes to it.

$\mathrm{H}^{*} \mathrm{~L}$

c. Presupposition structure of the complement clause in line 1 in (8a): "that Prince Charles [will] become an X monarch"

Questioned predicate: "X = "environmentally-conscious"?"

Effect on this presupposition structure created by the interpretation of THAT within its predicational context: "that Prince Charles [will] become monarch"

In (8a), what is highlighted in the context constituted by the interviewer's initial question, given the global topic at issue, is Prince Charles' ecological credentials, not whether in fact he would ever become king one day - a proposition which is presupposed by this speaker: the pre-nominal adjective GREEN was accented and pronounced with high pitch, while the head noun monarch was unaccented and carried a low level of pitch. The interviewee, however, though replying affirmatively to the question posed (Well, yes...), sought to call its presupposition into question; and he did this in part by using a strongly accented distal demonstrative pronoun (THAT) fulfilling a discourse-deictic function, in order to make accessible and salient an item of information which, in the context set up by the interpretation of the initial question, was in the background, not the foreground, of attention: the source of the referent evoked via construal of THAT is the governed clausal complement of think in the interviewer's first question. This is again in a micro-syntactic relation with the matrix clause; but the clause introduced by but in the interviewee's turn evidently contracts a macro-syntactic relation with the complement clause in the interviewer's first turn. I have attempted to formulate the information-structure representation of this segment of discourse under $(8 c)$.

In neither of the examples presented above could the retrieval have been effected felicitously via the use of a potentially anaphoric expression (for example, a reduced definite NP or a 3rd person pronoun: \#the boring Sundays or \#them in (7) and ?\#the idealthe possibility or \#it in (8a): see (8b)). Such indexical-expression types are specialised in the expression of anaphora, where the referent retrieved is assumed to be salient for the addressee/reader to some degree — the anaphoric segment simply carrying over the situation evoked in the antecedent unit. Such units are normally retrieved from the forefront of the discourse, the backgrounded segments serving to support or "anchor" them in some way.

Let us look now at example (9).

(9) 'I've written 14 musicals and don't have a huge desire to write another until I'm absolutely sure I want to invest that amount of time...". ("Staging a revival", RT Interview with Andrew Lloyd-Webber, Radio Times 5-11/08/06, p. 18)

In (9), the time taken to write a musical is not in focus or even accessible when the predication I've written 14 musicals is realised. It is the result of an inference drawn at the point of interpretation of the indexical. Hence the use of a distal demonstrative NP

'intermediate phrase boundary symbol. See Beckman and Elam (1997), Beckman et al. (2005) and Watson et al. (2008) for further details of this 'phonological' approach to intonation. 
that amount of time to refer to this aspect of the writing of a musical. The demonstrative pronoun \#that or the equivalent definite lexical NP (\#the amount of time) would not have been equal to the referential task required here. Again, as in the earlier examples we have seen (in spite of the fact that the exponent demonstrative NP occurs within a syntactically subordinate clause), the indexical reference occurs within a foregrounded segment, discursively, in relation to a referent derived from within a relatively backgrounded one, the two units arguably contracting a "macro-syntactic" relation with each other: we may analyse the initial "antecedent" clause as representing a backgrounded item of information in relation to the main, foregrounded content associated with the second conjunct (an explicit paraphrase would be "although I've written 14 musicals, I don't have a huge desire to write another until I'm absolutely sure I want to invest that amount of time"). The intonation contours associated with each conjunct would be continuative rather than conclusive (only the conditional subordinate clause until...time would be conclusive). See Brazil's (1997, Ch. 4) pragmaticallyrelevant distinction between two types of intonation contour in English: the so-called "referring tone" (fall-rise) and "proclaiming tone" (fall). Correspondingly, ErteschikShir's (2007) "lie-test" would be negative for each of the main clause conjuncts, but positive for the conditional clause introduced by until. See also examples (4) and (8) above.

Table 3 below summarises the distinction between the 'strict' anadeictic and discourse-deictic uses of demonstrative expressions.

Table 3: "Anadeictic" uses of demonstratives in English (revised version of Table 1 in Cornish, 2007:162)

\begin{tabular}{|c|c|c|}
\hline Parameters & 'Strict' anadeictic use & Discourse-deictic use \\
\hline $\begin{array}{l}\text { Referent is a determinate entity } \\
\text { already bearing a minimal level of } \\
\text { saliency }\end{array}$ & + & - \\
\hline $\begin{array}{l}\text { Requires understander to operate on } \\
\text { immediate discourse context, in order } \\
\text { to construct a new discourse entity }\end{array}$ & - & + \\
\hline $\begin{array}{l}\text { Possible introduction by a variety of } \\
\text { syntactic types of antecedent-trigger }\end{array}$ & - & + \\
\hline $\begin{array}{l}\text { Indexical expression can be replaced } \\
\text { by a definite NP where denotation of } \\
\text { NP's lexical component is } \\
\text { presupposed }\end{array}$ & + & - \\
\hline $\begin{array}{l}\text { Indexical expression substitutable by } \\
\text { an unaccented } 3^{\text {rd }} \text { person pronoun }\end{array}$ & $+?$ & - \\
\hline $\begin{array}{l}\text { Referent likely to persist in } \\
\text { subsequent discourse (pace Diessel } \\
\text { 1999) }\end{array}$ & + & - \\
\hline $\begin{array}{l}\text { Referent has no existence outside the } \\
\text { discourse, in "real" world (pace } \\
\text { Diessel 1999) }\end{array}$ & - & + \\
\hline
\end{tabular}

Sections 5 and 6 will try to identify the principles and constraints which relate discourse-anaphoric retrieval to referents associated with foregrounded discourse units, and 'strict' anadeictic and discourse-deictic reference with ones to be constructed from backgrounded or midgrounded units (the latter sub-type is not illustrated here, however). In particular, they will aim to determine the limits of anaphoric reference within the latter types of segments. 


\section{Discourse anaphora, 'strict' anadeixis and foregrounded vs. backgrounded discourse units}

Here now are two longer attested extracts (the first oral, the second written) where a subsequent reference to an already-introduced referent pops over a backgrounded segment to return to the "interrupted", main-line part of the discourse. But this is not done in the same way in each case.

Example (10) is an extract from an eye-witness account of the tsunami wave disaster as it affected the coast of Thailand in December 2004:

(10) (..) I noticed small kids and tourists walking to where the water had receded, curious as to why the water had gone.

Then I saw it - I noticed people craning their necks and looking out on the horizon. You could see a wall of water about three or four stories (sic) high. I felt like I was watching a movie, it was completely surreal.

It wasn't moving very quickly, it took between four and five minutes until I saw it hit and in that time slowly people started to realise what was happening. People were saying 'Oh God, what is that?' I thought I was dreaming.

After a few seconds the wave hit $\boldsymbol{\emptyset}$ and $\boldsymbol{\emptyset}$ smashed against the beach. (...)

(Extract from "Eyewitness: Panic in Patong", BBC News on the Web, 27.12.04)

In this extract from an originally oral monologue, it is a lexical NP (the wave) and not a pronoun (it), which is used in line 9 to refer to the tsunami wave, introduced (in part at least) in the main-line part of the narrative preceding the brief background segment in lines 7 and 8 . This is not due to the lack of salience in context of the intended referent (which is indeed the macro-topic-to-be at this point in the discourse). It is due in part to a purely discourse-structural factor: the fact that the introduction of 'the tsunami wave' by the narrator in lines 3-6 has been interrupted by his reference to the incredulous reactions of the people around him at the time (People were saying 'Oh God, what is THAT?'). This is a direct-speech report, which as such momentarily shifts the locutionary source - as well as of the point of view being expressed. See also the interrupting segment in example (11) (lines 2-5) below. Note furthermore the tense difference here (preterit for the reporting segment and simple present for the reported speech segment). So in returning to the main line of narration of the sequence of events after it, there is a need to "reset the cursor" to what is to be the macro-topic and the narration of its development.

Notice also that the tsunami wave has not yet been characterised as a 'wave': for the narrator uses a (mixed) metaphor in describing it in line 4 ("a wall of water about three or four storeys high" - my emphasis). This need to reset the cursor is further strengthened by the fact that the direct-speech quotation just given in line 8 has stressed the difficulty the bystanders faced at the time in characterizing (categorizing, more properly) what they were witnessing: this is highlighted precisely by their use of the stressed distal demonstrative pronoun THAT (as also used in (8a)) within an interrogative construction. In discourse terms, this reference will not yet have been ratified by the hearer or reader at this point in the text (or so the narrator assumes) - a state of affairs which calls for a lexically explicit, characterising expression type rather than a purely pronominal reference in line 9 .

In (11) below, by contrast, a possessive pronominal determiner and $3^{\text {rd }}$ person pronoun are used following a segment which is arguably "background" (a direct speech 
quotation from the subject of an interview, interrupting the 3rd person report by the journalist, and illustrating the point just made prior to it), connecting up with the foreground segment preceding it. Consider the interpretation of the pronouns in the last sentence of the following extract:

(11) “...He [Kenny Rogers] grew up with four brothers and three sisters, the son of a labourer and a cleaning lady, in a poor area of Houston, Texas. "My father was an alcoholic, but it wasn't disruptive because he was a wonderful man with a great sense of humour. The worst he did for our family was use money for alcohol rather than food or clothes. But he earned it, and had the right to get something out of life. He didn't drink for the last four years." His parents were not keen on him being a musician, and the early years were tough..." (Interview with Kenny Rogers, The Radio Times, 7-13.8.99, p. 18; example (17) in Cornish, 2002).

Observe, first, that there are two discourse segments ${ }^{16}$ in this extract: an "outer" or containing segment where it is the journalist who conducted the interview who is the locutionary source, and an inner, embedded segment corresponding to the direct speech section, where it is the interviewee, Kenny Rogers, who takes on the role of locutionary source. So this example is similar in this respect to example (10) above. The directspeech segment is explicitly delimited graphically via the opening and closing of the inverted commas, and via the switch from third-person to first-person pronouns in reference to the interviewee. But there are no differences as far as tense/aspect is concerned (unlike in example (10)). Note also that the local discourse topics of each segment are distinct: for the main discourse segment, this is 'Kenny Rogers', whereas for the embedded discourse segment, it is 'Kenny Rogers' father'. The direct speech segment is clearly background in relation to the feature article as a whole, since the latter is about Kenny Rogers, not his father. Direct-speech quotations are a favourite device used by journalists to create a sense of vividness in their reports, and to provide direct evidence for the more general points they may be making.

Once the direct-speech segment is terminated, it is "popped" from the highest position in the "focus stack" (according to Grosz and Sidner's 1986 hierarchy of "focus spaces" associated with given discourse segments), and its contents are therefore no longer available for anaphors (here the possessive determiner his and the third-person pronoun him in the final sentence) to pick up. And this corresponds to intuition, since these two anaphors are unambiguous in referring to Kenny Rogers, rather than to Kenny Rogers' father, the topic of the intervening direct-speech segment. These anaphors, in conjunction with the content of their host predicator and the closing of the inverted commas at the end of the immediately preceding sentence, effect a "return pop" to the main, interrupted segment, which is about Kenny Rogers himself — even though they are in this instance $3^{\text {rd }}$ person pronominal and not lexical anaphors, unlike the situation in (10). The reason is that the popped-over segment is felt as an interruption, whereby the popped-back-to segment is continued by the popping segment. It is thus still in an active state, in terms of discourse attention focus. Unlike example (10), the poppedback-to referent is already firmly installed in the addressee's mind at the point of return (and categorised as an entity of a particular type), and is no longer under construction.

(10) and (11) both involved "popping" references after a background segment to

\footnotetext{
${ }^{16}$ That is, basic discourse units, defined in part by their implementing a particular discourse purpose or goal relative to some more global discourse purpose: see Grosz and Sidner (1986) for both the term discourse segment and its definition and illustration.
} 
the foreground segment which "embeds" it, hierarchically. In (12) and (13) below, on the other hand, we have a (strict) anadeictic reference in (12) and an attempted anaphoric one in (13) to a referent previously evoked within a highly backgrounded segment, micro-syntactically connected to its governing one.

(12) “Asia

Pakistan quake toll tops 73,000

The death toll from Pakistan's earthquake soared to more than 73,000 and could still rise, according to official government figures. These are lower than those of other agencies, which estimate up to 87,000 dead. More than 3 million have been left homeless across Kashmir and North Western Frontier province." (The Guardian Weekly 11-17 November, 2005, p. 2. Example (4) in Cornish 2011).

In (12), the proximal demonstrative pronoun these, subject of the second sentence, refers " strict'-anadeictically" to 'the official Pakistani government figures $(73,000$ as of $11^{\text {th }}$ November 2005) on the death toll from Pakistan's then recent earthquake'. This referent has just been evoked via a peripheral expression, the adjunct PP according to official (Pakistani) government figures in the initial sentence of the text. This is a sentence modifier/adjunct specifying the source of the claim made by the journalist in the main part of this initial sentence; as such, it occupies a backgrounded slot, under Khalil's (2005) account. Indeed, this referent could not have been retrieved felicitously via a canonically anaphoric expression (here \#they), since it is not in focus at the point of occurrence. This is why a proximal demonstrative pronoun was used to retrieve it, "strict-anadeictically". Let us compare now what happens when an ordinary $3^{\text {rd }}$ person pronoun is used to retrieve a referent of this kind:

(13) "Militants want cleric freed

A militant Palestinian splinter group, the Islamic Army, has demanded that Britain release a Muslim cleric in return for the freedom of BBC reporter Alan Johnston. He was kidnapped on March 12." (The Guardian Weekly, 18/05/07, p. 2)

In (13), we find a very similar situation - in terms of the utterance context of the indexical. Here, the $3^{\text {rd }}$ person masculine singular human-denoting pronoun he, signalling canonical anaphora, is used to retrieve a referent introduced in a peripheral phrase within the initial sentence, the adjunct PP in return for the freedom of $B B C$ reporter Alan Johnston. Note that there could be a comma (or a pause in the spoken version) between the words cleric and in here, showing that this adjunct may be a sentence modifier. This is analogous to the situation prevailing in example (12), where an anadeictic, not a canonical discourse-anaphoric, expression was used to this end.

In fact, my feeling is that this use of he is infelicitous in this context. A more natural retrieval of this referent would have been via a reduced definite role-denoting $\mathrm{NP}$, such as the journalist (cf. the definite NP the wave as used in line 9 in example (10)). ${ }^{17}$ In addition, the use of he results in anaphoric ambiguity here (at least at the point where the pronoun he is encountered), since the macro-topic entity in this text is the Muslim cleric (not identified by name) whose release is demanded by the Palestinian splinter group, the Islamic army. Indeed, the cleric is mentioned in the very title, which highlights the essential point of the text as a whole. Moreover, this referent

\footnotetext{
17 Incidentally, this would provide support for the macro-syntactic relationship holding between the two sentences here (see the definite NP substitution test discussed in section 2 above).
} 
is introduced in the body of the text via an indefinite NP in direct object position within a complement clause, a grammatical function higher in the hierarchy of grammatical relations than the adjunct PP introducing the second male referent. ${ }^{18}$ However, once the predicative component of the anaphoric sentence is taken into account, only the BBC reporter may be said to have been "kidnapped"; for the Muslim cleric is presupposed to be held in custody by Britain at the time of publication. So there is a conflict here between the import of 'top-down' and of 'bottom-up' contextual information.

A key common feature in the four examples presented in this section concerns the topical status of the referent retrieved via the respective indexicals at the point where the retrieval occurs. In (10), the definite lexical NP the wave in line 9 is not anaphoric with respect to the contrastively-accented distal demonstrative pronoun THAT in the background (direct-speech) segment in line 8: for this is the first characterisation of the referent at issue as a "wave", and contrastive THAT in line 8 is a deictic, not an anaphoric occurrence. The clause in which the NP the wave occurs clearly resumes the narration of the sequence of events as perceived by the narrator: the progress of the tsunami wave. Unlike the situation in (11), where a $3^{\text {rd }}$ person pronoun and pronominal possessive determiner continue the macro-discourse topic already introduced and installed in the discourse within the main discourse unit preceding the direct-speech (background) interruption, in (10) the referent targeted by the NP the wave has not yet been installed in the discourse qua 'wave': it is only in line 9, immediately following the background direct-speech segment and closing it off as such, that this is achieved. By the time the background segment occurs, this introduction has not reached full completion. So it is only a lexically-headed indexical expression such as a full NP that could accomplish this task.

In both (12) and (13), it is a referent with relatively low salience, introduced in a backgrounded segment, which is retrieved. In (12), this retrieval is realised felicitously via a demonstrative expression (a plural proximal demonstrative pronoun), but the use in (13) of a $3^{\text {rd }}$ person pronoun is not a successful anaphoric retrieval, as we have seen. I would align (13), with the (more felicitous) use of a definite NP such as the journalist to retrieve the intended referent, with (10), which also involves the use of a definite lexical NP (the wave) as a retrieval device. For in (13) too, the referent to be continued in the indexical segment is not yet fully topical. An ordinary $3^{\text {rd }}$ person pronoun or pronominal determiner could therefore not achieve this retrieval felicitously. Thus a role-denoting lexical indexical is called for in each case: in (10) in order to finally characterise the referent being introduced and so to bring it to full topical status; and in (13) to distinguish the male referent intended from the already more highly topical male referent introduced and installed as macro topic at the point where the retrieval is to be achieved. Again, only a lexically-headed expression could felicitously realise this indexical reference.

\section{Summary and Conclusions}

First of all, our examples and discussion have shown, I think, contra what is argued in Unger (2006), that discourse is not a purely linear, "river-like" phenomenon, which "flows" along incrementally (though this may well be an accurate characterisation of

18 Cf. the Centering theory algorithm which uses a grammatical relations hierarchy to predict which referent introduced via an NP realizing one or other nuclear or non-nuclear GR is most likely to be retrieved via a topical nominal expression in later utterances (see Walker et al. (eds.) 1998). 
"text" in any context of use: see Table 1). There is a hierarchical structure to it, formed by segments assuming a foreground, midground or background relation with respect to other co-occurring segments; these segments may also be related paratactically, as "sister" units assuming the same "grounding" relation with respect to some other, dominating segment (see Walker 1998 on this point). The functioning of different types of indexicals in relation to entities evoked within these segments amply attests to this, as we have seen. For example, if an indexical expression refers in terms of a text segment which conveys presupposed information in relation to the host (anaphor-containing) segment, and the two segments contract a macro-syntactic relation with each other, then in order to achieve the reference intended, an expression realizing either 'strict' anadeixis or discourse deixis is normally used. In the former case, the referent will already be constructed and its discourse representation established in the prior discourse context; but in the latter, the referent has to be formed out of the relevant discourse context, in terms of what is predicated of this created referent. The use of a demonstrative-based expression together with its predicative context thus results in this referent not only coming into (discourse) existence, but being made salient and thus susceptible of being picked up again by a purely anaphoric expression. Table 3 in section 4 summarises the distinction.

Examples (7)-(9) involved background segments which are in a micro-syntactic relation with regard to their containing clauses, in Berrendonner's (1990), (2002) and Berrendonner et al.'s (forthcoming) terms, though the indexical-containing units are in a macro-structural one with regard to these segments as whole units; and the backgrounded segments in (10) and (11) are clearly in a macro-syntactic relation with respect to the more central discourse segments within which they occur. In (10) and (11), there is no subsequent reference within the "return-popping" (foreground) segment following the backgrounded one to an entity evoked within the latter. Interestingly, both references to what is objectively the same referent within the direct-speech background segments preceding the continuative (anadeictic or anaphoric) references are achieved deictically; and in each case also, these background segments evince a shift in locutionary source.

Where a canonical discourse-anaphoric expression is used (typically a $3^{\text {rd }}$ person pronoun), the referent must, as in the anadeictic case, be established as a salient entity in the context discourse representation; and correspondingly, it must also have been evoked within a foregrounded (or midgrounded) text segment, in Khalil's (2005) terms (compare examples (12) and (13) in this regard, in particular) - unless the initial evocation and the anaphoric one both occur within a micro-syntactic sequence, in Berrendonner's conception. Here, it is perfectly possible (indeed expected) for the retrieval to occur within a backgrounded segment - a status which usually corresponds to micro-syntactically related segments. Reduced definite NPs may be used felicitously both in the "strict'-anadeictic" and the discourse-anaphoric situations, though not in the "discourse deictic" one (see Table 3).

\section{Acknowledgements}

I am grateful to Alain Berrendonner and Esam Khalil for reading earlier drafts of sections 2 and 3, respectively, as well as to Laure Anne Johnsen, Philippe de Brabanter and four anonymous referees for their comments on earlier versions of this article. This text is an expanded, revised version of the paper which appeared in the on-line journal Discours 3 (http://discours.revues.org) in December 2008, with the title "When indexicals target 
discursively subsidiary information: How foregrounding and backgrounding in discourse affect indexical reference".

\section{References}

Andersen, Hanna. L., and Henning Nølke. (eds.). 2002. Macro-syntaxe et macrosémantique. Actes du colloque international d'Århus, 17-19 May 2001. Bern: Peter Lang.

Auer, Peter. 2009. "Context and contextualisation". In Key Notions for Pragmatics ed. by Jef Verschueren, and Jan-Ola Östman, 86-101. Amsterdam/Philadelphia: John Benjamins.

Avanzi, Matthieu. 2007. "Regards croisés sur la notion de macro-syntaxe". Travaux Neuchâtelois de Linguistique 49: 39-58.

Beckman, Mary E., and G.A. Elam. 1997. "Guidelines for ToBI labelling” ( $3^{\text {rd }}$ revision). The Ohio State University Research Foundation. (http://www.ling.ohiostate.edu/ tobi/ame_tobi/labelling_guide_v3.pdf)

Beckman, Mary E., Julia Hirschberg, and S. Shattuck-Hufnagel. 2005. "The original ToBI system and the evolution of the ToBI framework". In Prosodic Models and Transcription: Towards a Prosodic Typology ed. by S-A. Jun, 9-54. Oxford: Oxford University Press.

Berrendonner, Alain. 1990. "Pour une macro-syntaxe". Travaux de Linguistique 21: 2536.

Berrendonner, Alain. 2002. Ch. 2: "Morpho-syntaxe, pragma-syntaxe, et ambivalences sémantiques". In Andersen and Nølke (eds.), 23-41.

Berrendonner, Alain, Denis Apothéloz, Marie-José Béguelin, Laurence Benetti, and Françoise Zay. (forthcoming). Ch. 3: Les clauses : délimitation syntaxique. In Grammaire de la période. Paris: Champion.

Blanche-Benveniste, Claire. 2002. Ch. 5: "Macro-syntaxe et micro-syntaxe : les dispositifs de la rection verbale”. In Andersen and Nølke (eds.), 95-118.

Boye, K., and Peter Harder. 2009. "Evidentiality: Linguistic categories and grammaticalization". Functions of Language 16(1): 9-43.

Brazil, David. 1997. The Communicative Value of Intonation in English. Cambridge/New York/Melbourne: Cambridge University Press.

Bühler, Karl. 1990/1934. Theory of Language: The representational function of language. Amsterdam: John Benjamins.

Chapman, Siobhan. 1998. Accent in Context. Bern: Peter Lang.

Chomsky, Noam. 1986. Knowledge of Language. New York: Praeger.

Clark, Herbert H., and A. Bangerter. 2004. Ch. 2: "Changing ideas about reference". In Experimental Pragmatics, ed. by I.A. Noveck, and Dan Sperber, 25-49. Basingstoke: Palgrave Macmillan.

Cornish, Francis. 1999. Anaphora, Discourse and Understanding. Evidence from English and French. Oxford: Clarendon Press.

Cornish, Francis. 2002. "Anaphora: Lexico-textual structure, or means for utterance integration within a discourse? A critique of the Functional Grammar account". Linguistics 40 (3): 469-493.

Cornish, Francis. 2007. "English demonstratives: Discourse deixis and anaphora. A discourse-pragmatic account". In Interpreting Utterances: Pragmatics and its Interfaces. Essays in honour of Thorstein Fretheim, ed. by R.A. Nilson, N. A. 
Appiah Amfo, and K. Borthen, 147-166. Oslo: Novus Press;

Cornish, Francis. 2008. "How indexicals function in texts: Discourse, text, and one neoGricean account of indexical reference". Journal of Pragmatics 40(6): 997-1018.

Cornish, Francis. 2010. "Anaphora: Text-based or discourse-dependent? Functionalist vs. formalist accounts". Functions of Language 17(2): 207-241.

Cornish, Francis. 2011. "Strict' anadeixis, discourse deixis and text structuring". Language Sciences 33(5): 753-767.

Diessel, Holger. 1999. Demonstratives. Form, function and grammaticalization. Amsterdam: John Benjamins.

Diessel, Holger. 2006. "Demonstratives, joint attention, and the emergence of grammar". Cognitive Linguistics 17(4): 463-489.

Dik, Simon C. 1997. Ch. 13 in The Theory of Functional Grammar Part I: The structure of the clause (ed. by K. Hengeveld), 309-338. Berlin: Mouton de Gruyter.

Dowty, David R. 1986. "The effects of aspectual class on the temporal structure of discourse: Semantics or pragmatics?". Linguistics and Philosophy 9: 37-61.

Duranti, Alessandro, and Charles Goodwin. (eds.). 1992. Rethinking Context: Language as an interactive phenomenon. Cambridge: Cambridge University Press.

Ehlich, Konrad 1982. Anaphora and deixis: Same, similar, or different? In Speech, Place and Action. Studies in deixis and related topics, ed. by R. J. Jarvella, and W. Klein, 315-338. Chichester: John Wiley.

Erteschik-Shir, Nomi. 2007. Information Structure. The syntax-discourse interface. Oxford: Oxford University Press.

Gennari, S.P. 2004. "Temporal references and temporal relations in sentence comprehension". Journal of Experimental Psychology: Learning, Memory and Cognition 30(4): 877-890.

Gerner, Matthias. 2009. "Deictic features of demonstratives: A typological survey with special reference to the Miao group". Canadian Journal of Linguistics/Revue canadienne de linguistique 54(1): 43-90.

Givón, Talmy. 1987. "Beyond foreground and background". In Coherence and Grounding in Discourse, ed. by Russell S. Tomlin, TSL vol 11, 175-188. Amsterdam/Philadelphia: John Benjamins.

Griffiths, Patrick. 2006. An Introduction to English Semantics and Pragmatics. Edinburgh: Edinburgh University Press.

Grosz, Barbara J., and Candace L. Sidner. 1986. "Attention, intentions, and the structure of discourse". Computational Linguistics 12: 175-204.

Hanks, William F. 1992. "The indexical ground of deictic reference". In Rethinking Context: Language as an interactive phenomenon, ed. by A. Duranti, and C. Goodwin, 43-76. Cambridge: Cambridge University Press.

Hopper, Paul. 1979. "Aspect and foregrounding in discourse". In Syntax and Semantics Vol. 12: Discourse and Syntax, ed. by Talmy Givón, 213-241. New York: Academic Press.

Huang, Yan. 2000. Anaphora. A cross-linguistic study. Oxford: Oxford University Press.

Jadir, Mohammed. 2005. La cohérence du discours en Grammaire Fonctionnelle. Le cas du texte narratif. Rabat: Bouregreg.

Khalil, Esam. N. 2005. "Grounding: Between figure-ground and foregroundingbackgrounding". Annual Review of Cognitive Linguistics 3: 1-21.

Kies, D. 1994. "Adverbial but". In The Twentieth LACUS Forum 1993, 315-332. Lake 
Buff, IL: Jupiter Press.

Kleiber, Georges. 1994. Anaphores et pronoms. Louvain-la-Neuve: Duculot.

Lyons, John. 1975. "Deixis as the source of reference". In Formal Semantics of Natural Language, ed. by Edward. L. Keenan, 61-83. Cambridge: Cambridge University Press. Reprinted as Ch. 8 in Lyons, John. 1991. Natural Language and Universal Grammar, 146-165. Cambridge: Cambridge University Press.

Lyons, John. 1977. Ch. 15: "Deixis, space and time". In Semantics, Vol 2, 636-724. Cambridge: Cambridge University Press.

Madden, C.J., and R.A. Zwaan. 2003. "How does verb aspect constrain event representations?". Memory and Cognition 31(5): 663-672.

Mittwoch, Anita. 1983. "Backward anaphora and discourse structure". Journal of Pragmatics 7(2): 129-139.

Pierrehumbert, Jane, and Julia Hirschberg. 1990. "The meaning of intonational contours in the interpretation of discourse". In Intentions in Communication, ed. by P.R. Cohen, J. Morgan, and M.E. Pollack, 271-311. Cambridge, Mass.: MIT Press.

Piwek, Paul, R-J. Beun, and Anne Cremers. 2008. "'Proximal' and 'distal' in language and cognition: Evidence from deictic demonstratives in Dutch". Journal of Pragmatics 40: 694-718.

Reinhart, Tanya. 1984. "Principles of gestalt perception in the temporal organization of narrative texts". Linguistics 22: 779-809.

Sidnell, Jack. 2009. Deixis. In Key Notions for Pragmatics, ed. by Jef Verschueren, and Jan-Ola Östman, 114-138. Amsterdam/Philadelphia: John Benjamins.

Unger, Christoph. 2006. Ch.4: "Global coherence and grounding in discourse". In Genre, Relevance and Global Coherence. The pragmatics of discourse type, 72103. Basingstoke: Palgrave Macmillan.

De Vega, M., M. Rinck, J.M. Díaz, and I. Léon. 2007. "Figure and ground in temporal sentences: The role of the adverbs when and while". Discourse Processes 43(1): $1-23$.

Walker, Marylin A. 1998. "Centering, anaphora resolution, and discourse structure". Ch. 19 in Walker, Joshi and Prince (eds.), 401-435.

Walker, Marylin A., Aravind K. Joshi, and Ellen F. Prince. (eds.) 1998. Centering Theory in Discourse. Oxford: Clarendon Press.

Watson, David G., Michael K. Tanenhaus, and C. A. Gunlogson. 2008. "Interpreting pitch accents in online comprehension: $\mathrm{H}^{*}$ vs. $\mathrm{L}+\mathrm{H}^{*}$ ". Cognitive Science 32(7): 1232-1244. 